
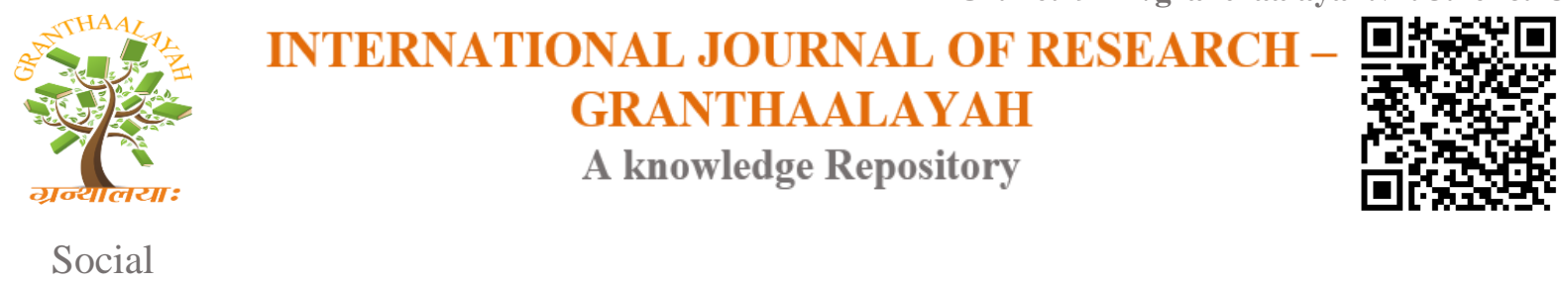

\title{
CONSTRAINTS FACED BY PERSONS WITH DISABILITIES IN EMPLOYMENT
}

\author{
Poonam Dhanda *1, Dr. Alok Kumar Mishra ${ }^{2}$ \\ ${ }^{*}$ PhD Scholar Department of Social Work TMU, INDIA \\ ${ }^{2}$ HOD Department of Social Work TMU, INDIA
}

\begin{abstract}
The study is absolutely an observational study used to measure empowerment of persons with disabilities through the improvement of entrepreneurial quality, development and imagination. Further research is expected to create, assess, evaluate, the significance of present study in other developing nations. India is frequently depicted as a developing yet a youthful nation. As the nation enters its 65th year of autonomous presence the depiction of youth does not appear to be excessively suitable. It can now be termed youthful by reason of the way that half of its billion or more populace comprises of persons underneath 25 years old and $65 \%$ of the populace is beneath 35 years. Every single differently abled individual has a leftover potential force than their non-disabled companions. Six to seven rate of populace in India is individuals with inability almost 8 to 9 crore individuals the number is expanding with mishaps and maturing. About 33\% of aggregate number of individuals in India is influenced with some kind of incapacity.
\end{abstract}

Keywords:

Empowerment, Persons with disabilities, Financially Motivated, Employment and Employability.

Cite This Article: Poonam Dhanda, and Dr. Alok Kumar Mishra, "CONSTRAINTS FACED BY PERSONS WITH DISABILITIES IN EMPLOYMENT”' International Journal of Research Granthaalayah, Vol. 4, No. 3 (2016): 182-187.

\section{INTRODUCTION}

The present study on employment of persons with different sorts of capacities is enlivened by this key idea: given appropriate undertakings and empowering environment any individual can demonstrate their value. In India, the worry about contrastingly abled persons is not across the board. Some progress has been made in building up organizations to give essential training. Innovative work exercises are still limited to couple of national organizations. These organizations have own needs, building up of a data base, is unquestionably not one among these. No big surprise that just detached endeavor has been made to gather and group data on occupation and professional recovery in particular areas. 
Studies on employment in the Railways by the National Institute of Mentally Disabled and work in vast commercial enterprises by the National Center for the Promotion of Employment of the Disabled Persons is two cases of uncommon endeavors made in India. Being more acquainted with the division, the examiners had picked the scholarly, science and innovation segment to gather, group and dissect data on livelihood and employability of diverse abled persons including persons having orthopedic challenges, listening to and discourse issue, vision troubles, mental hindrances, spastic, or a mix of such issues.

\section{WORLD SCENARIO}

Persons with disabilities make up an expected 15 for every penny of the world's populace, more than one billion- $80 \%$ of who live in creating nations. They every now and again encounter segregation and face boundaries to interest in all parts of society - for instance, in getting to Education, vocation, medicinal services and transportation. A few persons with disabilities confront different hindrances to their cooperation, because of segregation on the pretext of different grounds, including race, shading, sex, dialect, religion, political or other conclusion, national, ethnic, indigenous or social inception, property, conception and age. Therefore, persons with incapacities are at a high risk of neediness, which in itself improves the probability of having a disabled. Given that persons with inabilities speak to a critical segment of the world populace, and will probably live in neediness than their non-disabled associates, their consideration in all improvement exercises is vital, if universally concur advancement objectives, including the Millennium Development Goals (MDGs) are to be accomplished in a fair way.

The incorporation of persons with incapacities being developed programming likewise goes well from a financial point of view. Barring persons with inabilities from the universe of work has costs for social orders, as far as their gainful potential, the expense of disabled advantages or benefits, where these exist, and the suggestions for their families. This rejection may cost nations somewhere around 1 and 7 for each penny of Gross Domestic Product. These expenses to society can be minimized by disassembling boundaries to support of persons with inabilities, in instruction, abilities advancement, venture improvement and livelihood, and additionally neediness decrease and advancement programs.

\section{INDIAN CONTEXT}

Six to seven for every penny of the populace in India is incapacitated by statistics start from February 9, 2011. The 2001 enumeration discovered 21 million persons with incapacity that is $2.13 \%$ of the aggregate populace. There is an absence of political will in comprehension reality of inability issues which has prompted lacking designation of assets for the crippled in the nation. With a little national spending plan allotment, no big surprise the different measures which the legislature and the general public have taken for the welfare of the crippled touch just the edge of the issue. The pith of the visually impaired, the hard of hearing, the quiet, the slowwitted and the orthopedically disabled keeps on being upsetting. For the most part on account of the majority of them are poor, getting a charge out of no political clout, their requirements come very low in the request of needs of the administration. Whatever Government offices that are accessible for the crippled are in the way of minor crumbs. 
Exclusion from full cooperation in social and financial life and from training opportunities generously builds the risk of destitution. In India individuals living in destitution are at higher risk of genuine safety issues and miss chances because of confined access to social insurance, poor nutritious access, poor working and living conditions, which may prompt hindrance and exacerbate the current condition. In the event that a man obtains a sort of disability, he or she for the most part confronts boundaries to safety administrations, instruction, livelihood, and other open administrations, and gets himself/herself frequently denied the opportunities that could assist them with escaping destitution. Persons with disabilities can lead and cause neediness by keeping the full investment of persons with inabilities in the monetary and social existence of their groups, particularly if fitting bolster administrations and sensible settlement are not accessible. The connection in the middle of destitution and inability is because of segregation, social rejection and disavowal of rights together with absence of access to fundamental administrations, not the disability itself. A few persons with disabilities, for example, ladies, persons with scholarly, psychosocial or different incapacities and also elderly individuals, are more at risk of encountering destitution than others. In a few groups young ladies and ladies with incapacities get less care and sustenance, have less access to social insurance and recovery administrations and less instruction and job opportunities. They additionally have a tendency to have lower marriage prospects than young men or men with incapacities, and to be at a higher risk of physical, sexual and mental misuse.

\section{GOVERNMENTAL SCHEMES}

In India number of projects is being executed through national and peak establishments managing different classes of PWDs. These establishments lead short-and long haul courses for different classes of work force for giving recovery administrations to those requiring them. Under the Scheme of Assistance to the Disabled for Purchase/Fitting of Aids and Appliances (ADIP), around 2 lakh persons with inabilities are given assistive gadgets consistently. Amid 2010-11, 27.71 crore was discharged to actualizing organizations up to December 2010 against an overhauled allotment of ' 90 crore under the plan. The objective is to cover 2 lakh persons with inabilities. Under the Deen Dayal Disabled Rehabilitation Scheme (DDRS), 37.64 crore has been discharged up to December 2010 against a reconsidered portion of 90 crore amid 2010-11 to willful associations for running uncommon schools for children with hearing, visual, and mental inability and professional restoration communities for persons with different disabilities and for labor improvement in the field of mental impediment and cerebral palsy. The focused on number of recipients is 76,000 .

\section{LITERATURE REVIEW}

In India, the incapacity division all in all assessments that $4-5 \%$ of the populace is impaired, the Planning Commission perceives this figure as 5\%. A report by the World Bank expresses that while evaluations change, there is developing confirmation that persons with inability are around 40-80 million, which constitute between 4-8\% of India's populace. Both Census 2001 and NSS round of 2002 evaluation lower occurrence of incapacity in the nation. The Census of India demonstrated that the pervasiveness of incapacity in India was $2.2 \%$ interpreting into 21.9 million influenced people. 12.6 million are guys and 9.3 million females. Among the five sorts of incapacities on which information had been gathered in the 2001 Census, visual hindrance constituted $48.5 \%$; versatility disabled $27.9 \%$; mental disabled $10.3 \%$; discourse weakness $7.5 \%$ 
and listening to disability $5.8 \%$.. Regardless of the shifting assessments, in light of the sheer size of the Indian populace, even the least gauge of incapacity makes it equivalent to the number of inhabitants in a few European nations set up together. Seen in this viewpoint, persons with disabilities speak to the single biggest joined minority group in India.

Even the fact that impaired individuals constitute a noteworthy 5 to 6 rate of the number of inhabitants in India, their requirements for important occupation to a great extent remain unmet, disregarding the usage of 'The Persons with Disability' Act 1995 .This Act saves 3\% of all classifications of employments in the administration part for incapacitated persons, and gives vocation impetuses to open and private segment organizations, that have no less than $5 \%$ of their workforce including crippled persons. The distressing situation is of the roughly 70 million persons with inability in India, just around 0.1 million have succeeded in getting vocation in the commercial ventures till now. In a study led by National Center for Promotion of Employment for Disabled People (NCPEDP) on top 100 organizations in 1999, the rate of livelihood of disabled in private part was a troubling $0.28 \%$ and in multinational organizations, it was $0.05 \%$. The Annual report of the Ministry of Labor and employment(2007-8) demonstrates there are $6,87,632$ crippled individuals on the live enlist of the 81 Employment trades and extraordinary cells of the nation, holding up to land government positions. While numerous others have enlisted in private livelihood organizations, data on their enrolment and position is to a great extent inaccessible.

Employment rates of persons with incapacity fluctuate with geological area (urban or provincial), sexual orientation, instruction, and kind of inability. As per 2011 Census of India, $68 \%$ of India lives in country territories. Along these lines, in the general populace, the quantity of disabled is proportionately higher in country territories, complemented by general destitution contemplations and poor access to safety administrations. The country PWD is essentially detached from abilities and markets. Artistic levels are low, with the Census of India evaluating that $51 \%$ of persons with disabled are not proficient; $26 \%$ range up to the essential level; $6 \%$ center level and just $13 \%$ optional level or more

\section{RESEARCH METHODOLOGY}

The research is descriptive in nature explaining the constraints faced by persons with disabilities.

\section{CONSTRAINTS}

Some of the constraints persons with disabilities face in accessing labour markets are the following:

Low literacy levels: Literacy levels are low among offspring of all classes of incapacity. As indicated by the World Bank, absence of education is 52\% among PWD versus 35\% in the overall public. 25 As with the general populace, there are solid sex contrasts in instructive fulfilment among persons with incapacity, with female absence of education being $64 \%$ against crippled male lack of education of $43 \%$. Added to this is the way that numerous schools are not prepared to take into account the unique needs of the impaired in light of base, openness and accessibility of extraordinary teachers. Numerous persons with incapacity youth put resources into their instruction, doing combating family and societal obstructions which don't energize 
putting their restricted money related assets into teaching children with inability. Indeed, even in states with great instructive pointers and high general enrolments a critical offer of out of school youngsters are those with inabilities: Data additionally demonstrates that over all levels of seriousness, children with disability very rarely progress beyond primary school.

Lack of daily living skills: Many persons with disabilities are not prepared in essential living abilities like keeping up individual hygiene, grooming, travelling, use of washrooms, personal safety, etc.

Lack of self-esteem and confidence: Some persons with inability have low self-assumptions about their capacity to be utilized and may not attempt to discover work. The social detachment of persons with inability confines their entrance to interpersonal organizations, particularly of loved ones individuals that could help in discovering them employment. In country zones, persons with disabilities are disparaged or get tormented. At some point the folks likewise don't take them along for parties, and so on, because of the disgrace. This fortifies their mediocrity feeling and prompts low self - regard.

Overprotective parents: Many parents are exceptionally defensive about their special children, which can be an obstacle for the kid to end up autonomous. Numerous persons with incapacity are reliant either on their guardians, kin and companions for little errands, which makes it troublesome for them to autonomously look for job. More often than not they are escorted by their guardians/relatives, while organizations stress they need persons with incapacity who are independent.

Basic Skills: persons with disabilities might not have entry to circumstances of standard social connection, may have particular issues with correspondence (spellings for outwardly impeded don't get fortified by "seeing", sentence development for listening so as to listen to PWD don't get strengthened thus on prompting challenges in preparing them for employment.

Life Skills: This is an essential employability aptitude to land the position. Among the persons with disabilities competitors abilities like group building aptitudes, time administration, cash administration, are deficient with regards or weak.

Poor knowledge of English: Rural hopefuls with sensible capabilities have exceptionally poor information in English. Some of the time they can't even spell/compose their town name in English. This is a major test to make them work prepared in numerous administration segment occupations, including information section administrator, where least English learning is vital.

Lack of access to skills and technology: Education and preparing are fundamental to great and gainful work for a sensible pay. Be that as it may, youthful persons with incapacities regularly need access to formal training or to chances to build up their aptitudes, especially in the field of information technology.

Rural disconnect from markets: There are numerous differently abled youth who don't know about the preparation/openings for work accessible for them particularly in the rustic territories where inability is more intense. They are likewise not presented much to the external world and 
are secluded in their own reality. Innovative changes particularly new patterns like online enlistment make it troublesome for persons with inability to adapt, a considerable lot of who have never worked with computers before.

\section{CONCLUSIONS}

The study reports on various barriers creating obstacles in occupation for distinctively capable individuals. The study is critical as there is a crevice and nonappearance of Psycho-social exploration on the above referred to point. The study makes attention to the general public which will be instrumental in evacuating hindrances and permitting contrastingly capable individuals to awesome opportunities with respect to work. The examination study would likewise investigate causes from manager's viewpoints. Further the study will likewise make opportunities for contrastingly capable individuals whose stories have not been listened to.

\section{REFERENCES}

[1] Ooi Yeng Keat, Christopher Selvarajah, Denny Meyer. (2011). "Inclination towards entrepreneurship among university students: An empirical study of Malayasian University students" International Journal of Business and Social Science 2(4):206-220.

[2] Brown, Christopher Russell,(2007). "Economic theories of the entrepreneur: $A$ systematic review of the literature" Cranfield University, United Kingdom, ISBN.

[3] Jose c Sanchez, Andrea Gutierrez, (2011), "Entrepreneurship research in Spain: Developments and Distinctiveness" Psicothema 23(3):458-463.

[4] JaAnn C, Carland, James W. Carland, Wayne H Stewart (1996). "Seeing what's not there: The enigma of entrepreneurship”, Journal of Small Business Strategy,7(1),1-20.

[5] John C McIntosh, Samia Islam (2010), "Beyond the Veil: The influence of Islam on female entrepreneurship in a conservative Muslim context" International Management Review, 6(1):103-108.

[6] Swarna Jayanti Shahari Rozgar Yojana (2009), "Guidelines for the Scheme”

[7] Kondepati, R. (2014), "Andhra Pradesh's youth training and employment scheme: Did it work? Ideas For India”.

[8] ADB (2011), "Understanding Poverty in India”, Asian Development Bank, Manila.

[9] CII (2009), "A Values Route to Business Success: The why and how of employing persons with disability”, Confederation of Indian Industries, Delhi.

[10] CII (2010), "Indian IT/ITES Industry report", Confederation of Indian Industries, Delhi.

[11] GOI (2007-08), "Annual Report of Labor \& Employment”, Ministry of Labor and Employment, Government of India, India.

[12] GOI (2007-08), “Annual Report of Ministry of Rural Development”, Ministry of Rural Development, Government of India, India.

[13] GOI (2007-08), “Annual Report of Ministry of Social Justice\& Employment”, Ministry of Social Justice and Employment, Government of India, India.

[14] GOI (2012), "Eleventh five year plan report", Planning Commission, Government of India, India.

[15] IDFC (2009), “Indian Education, A long way from graduation”, Infrastructure Development Finance Company, India.

[16] World Bank (2007), "Development and Next Generation”, World Bank, Washington. 